\title{
Analisis Perencanaan Strategis Sistem Informasi Pada Madrasah Tsanawiyah Negeri
}

\author{
Analysis of Strategic Planning Information Systems of Madrasah \\ Tsanawiyah Negeri
}

\author{
Ahmad Rifki Harir*1, Bambang Soedijono ${ }^{2}$, Amir Fatah Soyan ${ }^{3}$ \\ ${ }_{1,2,3}$ Magister Teknik Informatika Universitak AMIKOM Yogyakarta \\ E-mail: * ${ }^{1}$ ahmad.1105@students.amikom.ac.id, ${ }^{2}$ bambang.s@ amikom.ac.id, \\ amir@amikom.ac.id
}

\begin{abstract}
Abstrak
Madrasah Tsanawiyah Negeri merupakan salah satu Sekolah Menengah Pertama yang berbasis Pendidikan Agama (Madrasah) yang terletah di Kabupaten Kebumen, Jawa Tengah. Dalam pengelolaannya Madrasah ini sudah menggunakan sistem informasi, namun pemanfaatannya belum digunakan sebagai salah satu alat strategis untuk memenangkan keunggulan kompetitif. Melainkan hanya sebatas pemanfaatan sistem informasi sebagai pendukung kegiatan operasional sekolah. Maka dari itu dibutuhkan sebuah perencanaan strategis sistem informasi untuk dapat unggul dengan kompetitior lainnya. Dalam pembuatan perencanaan strategis sistem informasi dalam paper ini menggunakan framework Ward \& Peppard. Dengan tahapan analisis lingkungan eksternal dan internal organisasi dengan memanfaatkan metode analisis yaitu SWOT, PEST, Value Chain, dan McFarland Strategic Grid. Setelah melakukan analisis internal dan eksternal maka akan diperoleh portofolio rekomendasi pengembanga sistem informasi yang dapat digunakan oleh organisasi. Pembuatan roadmap pengembangan aplikasi merupakan tahap terakhir dalam penelitian ini, yang mana dalam pembuatannya dalam kurun waktu lima tahun kedepan dengan pemetaan berdasarkan pada hasil kuesioner prioritas dna Mc Farland Strategic Grid.
\end{abstract}

Kata kunci-Perencanaan Strategis, Sistem Informasi, Ward \& Peppard, Portfolio.

\begin{abstract}
Madrasah Tsanawiyah Negeri is one of the Junior High School based on Religious Education (Madrasah) which is located in Kebumen Regency, Central Java. In its management, this Madrasah has used an in information system, but its use has not yet been used as a strategic tool to win a competitive advantage. But only limited to use of information systems to support school operational activities. Therefore, it takes an information system strategic planning to be able to excelwith other competitors. In making strategic planning of information systems in this paper using the Ward \& Peppard framework. With the stages of analysis of the external and internal environment of the organization using analysis methods, namely SWOT, PEST, Value Chain, and Mc Farland Strategic Grid. After conducting internal and external analysis, a portofolio of recommendations for information system development will be obtained that can be use by the organization. Making an application development roadmap is the last stage in this research, which is in the making in the next five years with mapping based on the result of priority questionnaire and he Mc Farlan Strategic Grid.
\end{abstract}

Keywords - Strategic Planning, Information Systems, Ward \& Peppard, Portfolios. 


\section{PENDAHULUAN}

Pada penerapan upaya SI/TI ada tiga sasaran dalam organisasi [1]. Pertama, memperbaiki efisiensi kerja dengan melakukan otomatisasi berbagai proses yang mengelola informasi. Kedua, meningkatkan keefektifan manajemen dengan memuaskan kebutuhan informasi guna pengambilan keputusan. Ketiga, memperbaiki daya saing atau meningkatkan keunggulan kompetitif organisasi dengan merubah gaya cara berbisnis.

Sistem informasi telah berkembang dari waktu ke waktu. Perkembangan dari teknologi informasi ini menyebabkan perubahan - perubahan peran, dari peran efisiensi dan efektivitas menjadi peran strategik. Peran efisiensi yaitu menggantikan tugas manusia dengan teknologi informasi yang lebih efektif. Sekarang peran teknologi informasi tidak hanya untuk efisiensi dan efektifitas melainkan juga peran strategik untuk memenangkan persaingan [2].

Madrasah Tsanawiyah Negeri merupakan sekolah Menengah Pertama yang bertujuan membentuk Akhlaq Mulia dan para calon Tahfidz Al-Qur'an, yang berada di Kebumen, Jawa Tengah. Dalam pengelolaannya Madrasah ini sudah menggunakan sistem informasi, namun pemanfaatannya belum digunakan sebagai salah satu alat strategis untuk memenangkan keunggulan kompetitif. Melainkan hanya sebatas pemanfaatan sistem informasi sebagai pendukung kegiatan operasional sekolah. Maka dari itu dibutuhkan sebuah perencanaan strategis sistem informasi untuk dapat unggul dengan kompetitior lainnya.

Berdasarkan permasalahan yang ada, maka rumusan masalah yang diusulkan adalah (a) bagaimana analisis sistem informasi dari sisi internal dan eksternal di Madrasah Tsanawiyah Negeri, (b) bagaimana bentuk portfolio sistem informasi untuk masa mendatang bagi manajemen organisasi.

Dengan adanya penelitian ini bertujuan untuk membuat perencanaan strategis sistem informasi guna meningkatkan keunggulan kompetitif serta membuat kerangka portfolio sistem informasi pada Madrasan Tsanawiyah Negeri.

Penelitian ini merujuk kepada beberapa penelitian sebelumnya yang pernah dilakukan. Seperti oleh (Maksum, 2019) yang melakukan penelitian pada SMK Syuabanul Wathon untuk membuat perencanaan strategis sistem informasi untuk dapat meingkatkan keunggulan kompetitif serta membuat portofolio sistem informasi [3]. Penelitian ini menggunakan framework Ward \& Peppard.

Pada tahun 2015, Ina Sholihah melakukan penelitian dengan topik yang serupa, yaitu membuat perencanaan strategis untuk Sekolah Islam Terpadu Salman Al Farisi Yogyakarta [4]. Dalam penelitian ini dilakukan beberapa tahapan analisis, yaitu analisis lingkungan internal eksternal organisasi dan analisis internal eksternal sistem informasi. Hasil dari penelitian ini yaitu berupa portfolio aplikasi pengembangan sistem informasi dan roadmap pengembangan dalam waktu lima tahun kedepan.

Penelitian selanjutnya dilakukan oleh (Dany, 2019) yang mana penelitian ini bertujuan untuk membuat perencanaan strategis sistem informasi pada KB-TK, SD, dan SMP [5] dengan menggunakan metode Ward \& Peppard yang dikombinasikan dengan Enterprise Architecture Planning (EAP).

\section{METODE PENELITIAN}

Pada penelitian ini menggunakan framework Ward \& Peppard yang akan digunakan sebagai metode analisis dari sisi internal dan sisi eksternal sehingga menghasilkan strategi sistem informasi yang tepat sesuai kebutuhan organisasi.

\subsection{Metode Pengumpulan Data}

Dalam penelitian ini digunakan beberapa teknik dalam pengumpulan data. Data yang dibutuhkan dikelompokan menjadi data primer dan data sekunder. Data primer merupakan data yang diperoleh langsung dari responden dan lapangan, kemudian data sekunder adalah data 
yang diperoleh secara tidak langsung. Metode yang digunakan dalam pengumpulan data antara lain :

1. Wawancara kepada pihak terkait pengembangan sistem informasi pada Madrasah. Wawancana langsung kepada KAMAD dan KA TU pada Madrasah Tsanawiyah Negeri.

2. Observasi bertujuan untuk mengetahui situasi dan kondisi internal serta eksternal organisasi. Metode ini digunakan sebagai penguat dari hasil pengumpulan data dengan metode wawancara.

3. Studi dokumentasi dilakukan untuk mempelajari dokumen pendukung dalam perancangan strategis sistem informasi.

4. Kuesioner digunakan untuk mengumpulkan data dari responden mengenai rekomendasi pengembangan sistem informasi yang diusulkan.

\subsection{Metode Analisis Data}

Dalam melakukan analisis data digunakan pendekatan framework Ward \& Peppard yang memiliki langkah - langkah sebagai berikut :

1. Analisis lingkungan bisnis internal (Value Chain)

2. Analisis lingkungan bisnis eksternal (SWOT, PEST)

3. Analisis lingkungan sistem informasi internal (Mc Farland Strategis Grid)

4. Analisis lingungan sistem informasi eksternal

\subsection{Alur Penelitian}

Alur penelitian dapat dilihat pada gambar 1 .

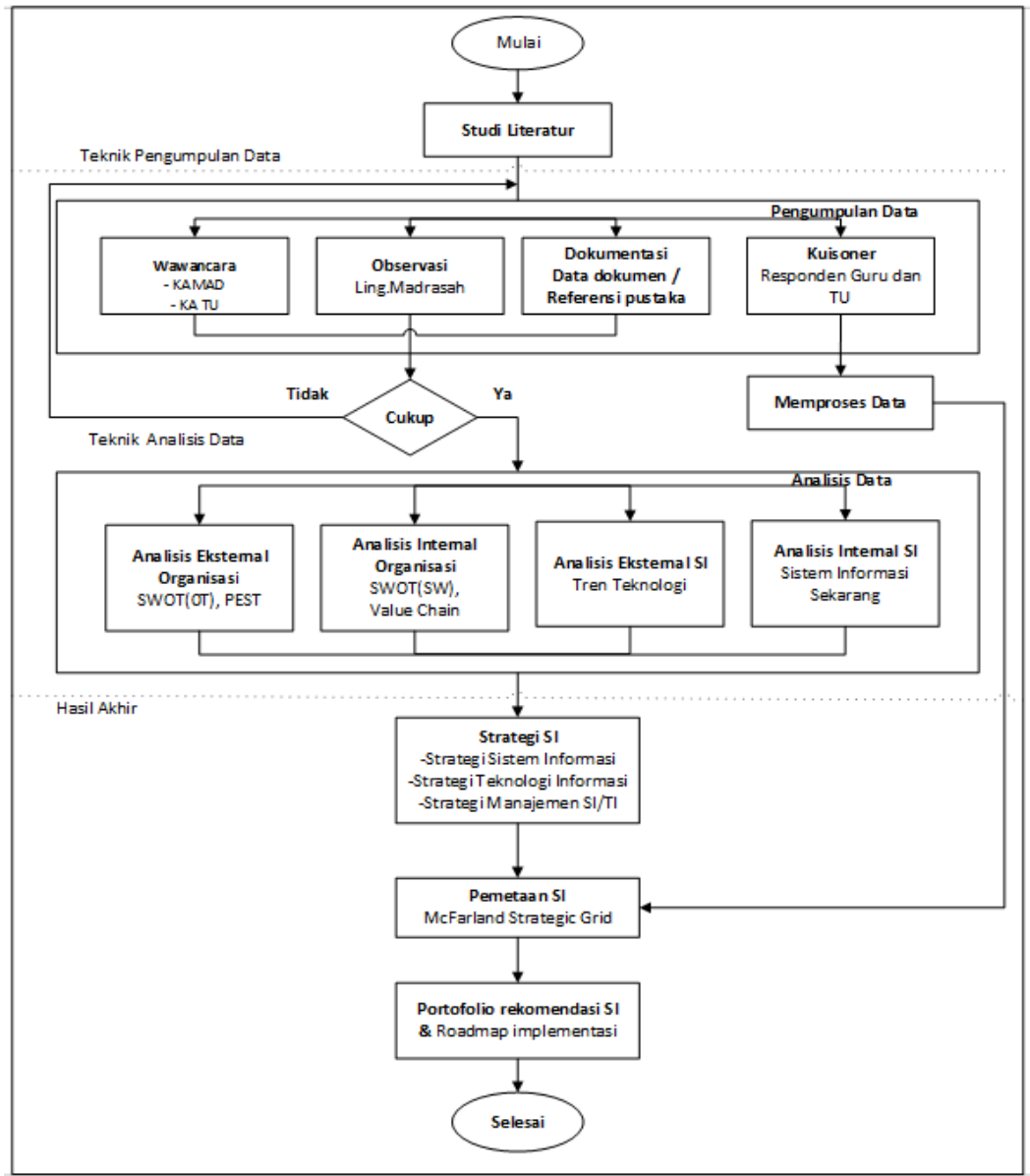

Gambar 1. Alur Penelitian 


\section{HASIL DAN PEMBAHASAN}

\subsection{Analisis PEST}

Analisis PEST bertujuan untuk mengetahui kondisi eksternal organisasi pada Madrasah Tsanawiyah Negeri yang dilihat dari faktor Sosial, Ekonomi, Politik, dan Teknologi. Hasil analisis PEST dapat dilihat pada gambar 2.

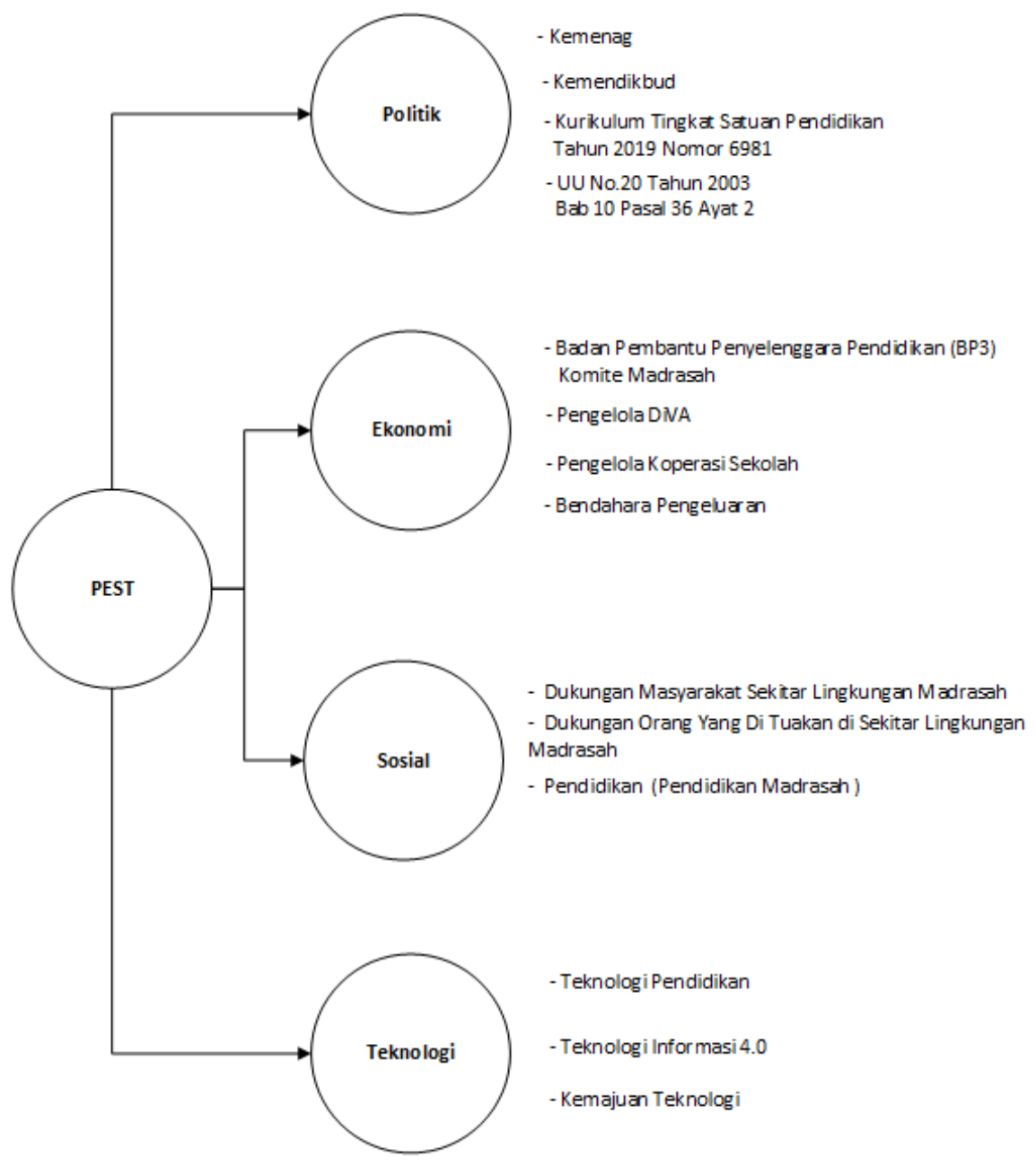

Gambar 2. Analisis PEST

Berdasarkan penjelasan diatas analisis PEST yang ditunjukan pada gambar nomor 2 menjelaskan bahwa faktor dari segi eksternal organaisasi yang mempengaruhi dari Madrasah Tsanawiyah Negeri adalah (1). Politik yaitu : Kementrian Agama RI (Bertanggung jawab atas belajar mengajar dan lingkungan madrasah, Kementrian Pendidikan dan Kebudayaan RI ( Bertanggung jawab atas peyelenggaraan buat ujian nasional ), Kurikulum Tingkat Satuan Pendidikan Tahun 2019 Nomor 6981 [6], UU Nomor 20 Tahun 2003 Tentang Pendidikan Nasional Bal 1 Pasal 36 ayat 2 [6], (2). Ekonomi : diawasi oleh Badan Pembantu Penyelenggaraan Pendidikan (BP3) sebagai pengawa komite madrasah, Pengelola Diva, Pengelolah Koperasi, Bendahara Pengeluaran (3). Sosial : Dukungan masyarakat sekitar lingkungan madrasah, Penmad (Pendidikan Madrasah), Dukungan orang yang dituakan dilingkungan madrasah ,(4). Teknologi : Teknologi Pendidikan , Teknologi Informasi 4.0, Kemajaun teknologi. 


\subsection{Analisis Value Chain}

Analisis selanjutnya yang digunakan untuk melakukan analisis lingkungan bisnis secara internal menggunakan analisis Value Chain. Yang mana analisis ini digunakan untuk mengidentifikasi proses bisnis yang ada pada organisasi. Analisis ini mengelompokan proses bisnis berdasarkan aktivitas utama dan aktivitas pendukung [2]. Hasil dari analisis ini seperti terlihat pada gambar 3 .

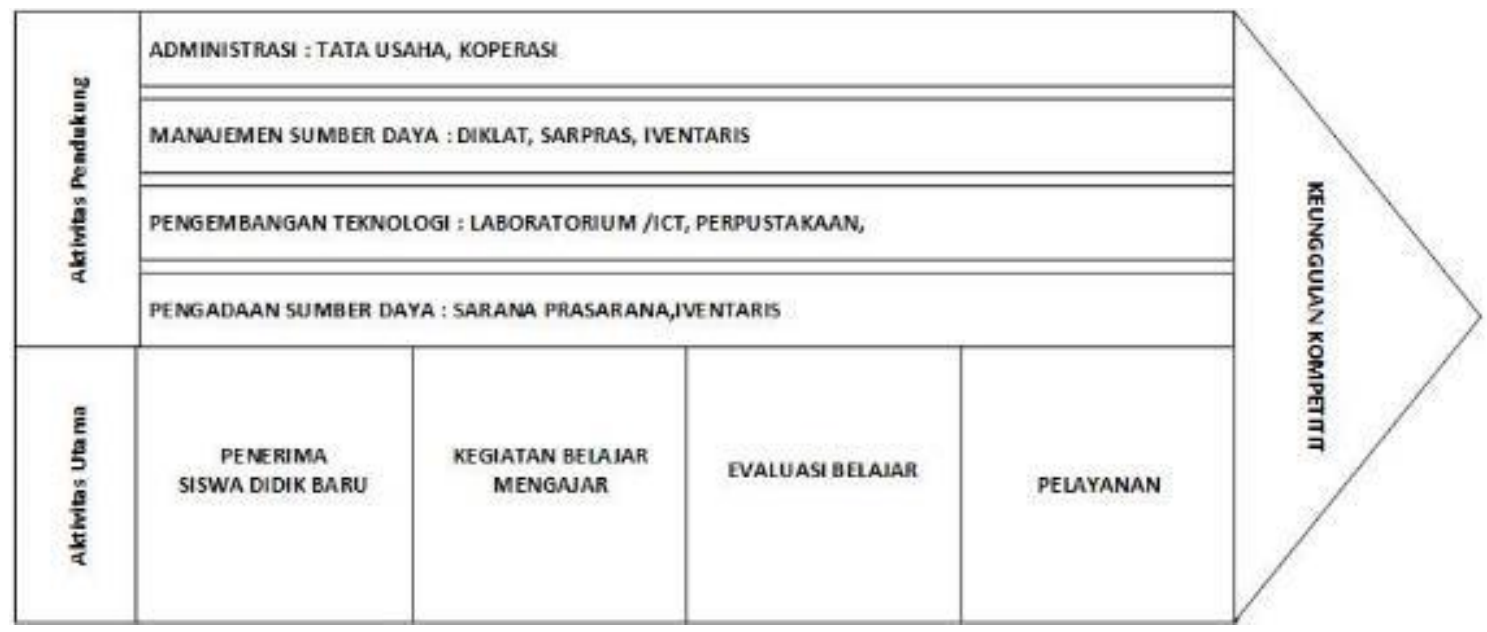

Gambar 3. Analisis Value Chain

Berdasarkan gambar 3 diatas, aktivitas utama pada Madrasah yaitu penerimaan peserta didik baru, kegiatan belajar mengajar, evaluasi belajar, dan pelayanan. Sedangkan untuk aktivitas pendukung antara lain administrasi, manajemen sumber daya, pengembangan teknologi, dan pengadaan sumber daya.

\subsection{Analisis SWOT}

Analisis SWOT identifikasi faktor untuk merumuskan strategi organisasi. Analisis SWOT memaksimalkan kekuatan (strength) dan peluang (opportunity), serta meminimalkan kelemahan (weakness) dan ancaman (threats). Analisis SWOT juga berguna untuk pengambilan keputusan mengenai pengembangan misi, tujuan, strategi, serta kebijakan organisasi [5]. Untuk analisis SWOT disajikan pada tabel 1.

Tabel 1. Analisis SWOT

\begin{tabular}{|c|c|}
\hline Kekuatan (Strength) & Kelemahan (Weakness) \\
\hline $\begin{array}{ll}\text { - } & \text { Bertempat disebuah desa strategis } \\
\text { - } & \text { Diterima masyarakat sekitar dengan } \\
\text { reputasi bagus } \\
\text { - } & \text { Lingkungan area yang luas } \\
\text { - } & \text { Memiliki berbagai fasilitas sarana dan } \\
\text { prasarana memadai } \\
\text { - } \quad \text { Tenaga pendidik yang berkompenten dan } \\
\text { berahklak muliah } \\
\text { - } \quad \text { Tanah dan Gedung milik sendiri } \\
\text { - } & \text { Sekolah Tingkat Pertama berbasis } \\
& \text { Pendidikan Agama } \\
\text { - } & \text { Peserta Didik yang berakhlak muliah } \\
\text { - } & \text { Komite Sekolah }\end{array}$ & 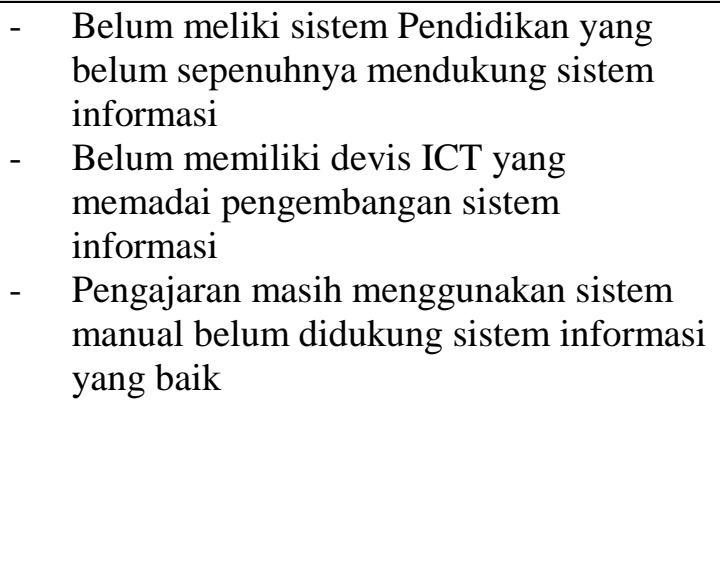 \\
\hline
\end{tabular}




\begin{tabular}{|c|c|}
\hline Kekuatan (Strength) & Kelemahan (Weakness) \\
\hline $\begin{array}{ll}\text { - } & \text { Adiyatma program bersih dan sehat } \\
\text { lingkungan sekolah }\end{array}$ & \\
\hline $\begin{array}{l}\text { Peluang (Opportunity) } \\
\end{array}$ & Ancaman (Threat) \\
\hline 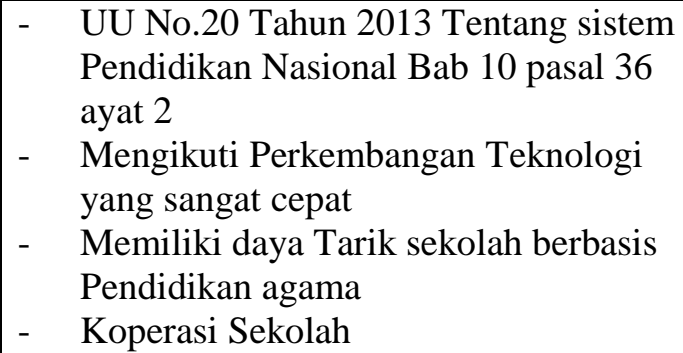 & $\begin{array}{ll}\text { - } & \text { Pesaing sekolah serupa berbasis } \\
\text { Pendidikan agama yang berada diseluruh } \\
\text { Indonesia } \\
\text { - Kurang sumber daya manusia yang } \\
\text { memilki keahlian dibidang it }\end{array}$ \\
\hline
\end{tabular}

\subsection{Rekomendasi Sistem Informasi}

Berdasarkan analisis sistem informasi diatas bisa dilihat dari proses bisnis ternyata ada hubungan antara proses bisnis dan solusi sistem informasi didasarkan pada aktivitas utama dan pendukung dari Madrasah Tsanawiyah Negeri. Bisa dilihat hubungan dalam tabel 2 berikut ini :

Tabel 2 Rekomendasi Sistem Informasi

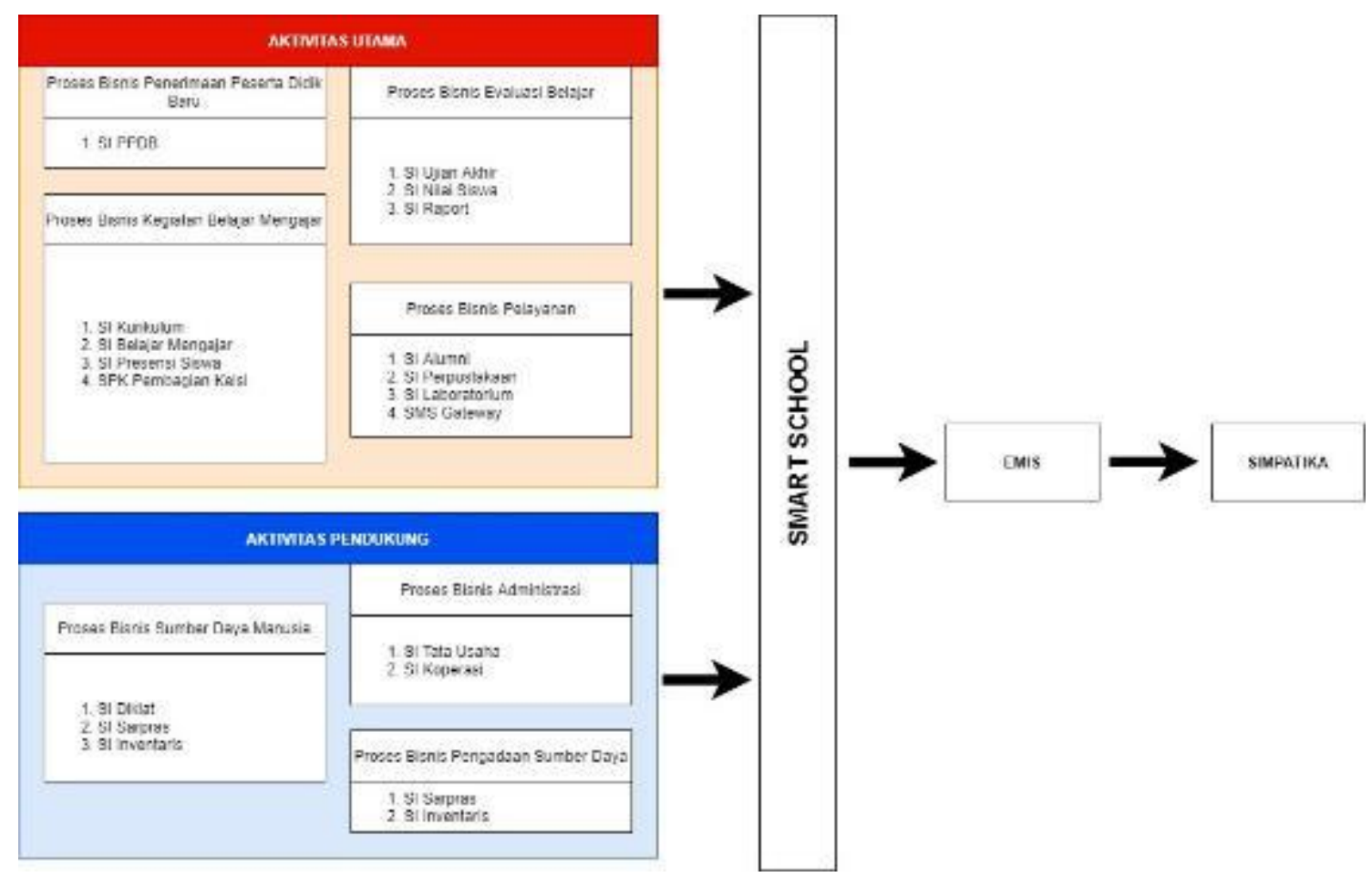

\subsection{Analisis Portofolio Sistem Informasi}

Berdasarkan proses penentuan aplikasi dalam hubungan dengan proses bisnis, maka dilakukan analisis terhadap aplikasi portofolio. Setiap apalikasi yang di defenisikan dalam arsitektur aplikasi memiliki kontribusi terhadap bisnis yang sedang berjalan saat ini da pada masa mendatang bagi organisasi. Berdasarkan aplikasi yang telah didefenisikan pada arsitektur aplikasi, maka setiap aplikasi dapat diklasifikasikan ke dalam jenis aplikasi menurut aplikasi 
portofolio. Berdasarkan hasil pertemuan dan pembahasan dengan stackholder terkait, maka portofolio aplikasi disajikan pada tabel 3

Tabel 3 Portofolio Aplikasi Madrasah Tsanawiyah Negeri

\begin{tabular}{|l|l|}
\hline Strategic Application & High Potential Application \\
\hline PPBD Online & Sistem Informasi Iventaris \\
Sistem Informasi Laboratorium & Sistem Penunjang Keputusan Pembagian \\
Sistem Informasi Sarpras & Kelas \\
\hline Sistem Informasi Kurikulum & Sistem Informasi Perpustakaan \\
Sistem Informasi Belajar Mengajar & Sistem Informasi Alumni \\
Sistem Informasi Presensi Siswa & Sistem Informasi Koperasi \\
Sistem Informasi Ujian & Sistem Informasi Diklat \\
Sistem Informasi Nilai Siswa & \\
Sistem Informasi Raport & \\
SMS Gateway & \\
\hline Key Operational Application & Support Application \\
\hline
\end{tabular}

Berdasarkan dari beberapa analisis yang telah dilakukan maka diproleh roadmap pengembangan implementasi usulan sistem informasi dalam 5 tahun mendatang. Bisa dilihat dari tabel 4 Roadmap Pengembangan Sistem Informasi :

Tabel 4 Roadmap Pengembangan Sistem Informasi

\begin{tabular}{|c|c|c|c|c|c|c|}
\hline \multirow{2}{*}{ No } & \multirow{2}{*}{ Sistem Informasi } & \multicolumn{5}{|c|}{ Tahun } \\
\hline & & 2021 & 2022 & 2023 & 2024 & 2025 \\
\hline 1 & Sistem Informasi Kurikulum & & & & & \\
\hline 2 & Sistem Informasi Belajar Mengajar & & & & & \\
\hline 3 & Sistem Informasi Presensi Siswa & & & & & \\
\hline 4 & Sistem Informasi Ujian & & & & & \\
\hline 5 & Sistem Informasi Nilai Siswa & & & & & \\
\hline 6 & Sistem Informasi Raport & & & & & \\
\hline 7 & SMS Gateway & & & & & \\
\hline 8 & Sistem Informasi Perpustakaan & & & & & \\
\hline 9 & Sistem Informasi Alumni & & & & & \\
\hline 10 & Sistem Informasi Koperasi & & & & & \\
\hline 11 & Sistem Informasi Diklat & & & & & \\
\hline 12 & $\begin{array}{l}\text { Sistem Penunjang Keputusan } \\
\text { Pembagian Kelas }\end{array}$ & & & & & \\
\hline 13 & Sistem Informasi Iventaris & & & & & \\
\hline 14 & PPBD Online & & & & & \\
\hline 15 & Sistem Informasi Laboratorium & & & & & \\
\hline 16 & Sistem Informasi Sarpras & & & & & \\
\hline
\end{tabular}

\section{KESIMPULAN}

Berdasarkan hasil pembahasan yang telah dijelaskan sesuai dengan tahapan penelitian terkait Analisis Perencanaan Strategis Sistem Informasi menggunakan Ward and Peppard pada Madrasah Tsanawiyah Negeri : 
1. Perencanaan Strategis yang dihasilkan dengan menggunakan Ward and Peppard yang sudah jelas dalam hal solusi sistem informasi pada setiap aspek kegiatan di Madrasah Tsanawiyah Negeri

2. Ada 16 Rekomendasi Sistem Informasi terdiri dari : (1) Sistem Informasi Strategic $=3$, (2) Sistem Informasi Key Operasional = 7, (3) Sistem Informasi High Potensial = 2, (4) Sistem Informasi Support $=4$

\section{SARAN}

Penulis memahami bahwa penelitian Analsis Perencanaan Strategis Sistem Informasi dengan metode Ward and Peppard ini masih memiliki kekurangan. Oleh karena itu, peneliti menyarankan terhadap pihak yang akan meneliti melakukan lebih mendalam tentang Analisis Perencanaan Strategis Sistem Informasi.

\section{UCAPAN TERIMA KASIH}

Penulis mengucapkan terima kasih kepada Tuhan Yang Maha Esa yang telah memberikan kelancaran penulis dalam melakukan penelitian. Tidak lupa kepada Kamad Madrasah dan beserta Guru dan Staff di lingkungan Tsanawiyah Negeri yang telah membukakan pintu untuk peneliti untuk melakukan penelitian. Serta Dosen pembimbing dan Dosen konsultasi.

\section{DAFTAR PUSTAKA}

[1] J. P. Ward, Strategic Planning for Information Strategy, 3rd ed. England: LTD, 2002.

[2] H. Jogiyanto, "Sistem Informasi Strategik Untuk Keunggulan Kompetitif: Memenangkan Persaingan Dengan Sistem Teknologi Informasi," Garisbuku.com, 2005. .

[3] M. M. Hidayat and H. Al Fatta, "Perencanaan Strategis Sistem Informasi Menggunakan Metode Ward and Peppard di SMK Syubbanul Wathon," vol. XIV, no. November, pp. 39-45, 2019.

[4] I. S. Widiati, E. Utami, and H. Henderi, "Perencanaan Strategis Sistem Informasi Untuk Meningkatkan Keunggulan Kompetitif Sekolah Islam Terpadu," Creat. Inf. Technol. J., vol. 2, no. 4, pp. 329-340, 2015, doi: 10.24076/CITEC.2015V2I4.59.

[5] A. Wibowo, Suputro, Kristanto, Fajar, Dany, Utami, Ema, Nasiri, "Perencanaan Strategis Sistem Informasi Untuk Meningkatkan Keunggulan Kompetitif," CSRID (Computer Sci. Res. Its Dev. Journal), vol. 11, no. 3, pp. 149-157, 2020.

[6] P. P, D, Keputusan Direktur Jendral Pendidikan Islam Nomor 6981 Tentang KTSP Madrasah Tsanawiyah. 2019. 